\title{
Social stratigraphy in Late Iron Age Switzerland: stable carbon, nitrogen and sulphur isotope analysis of human remains from Münsingen
}

\author{
Negahnaz Moghaddam • Felix Müller • Albert Hafner • \\ Sandra Lösch \\ Received: 29 July 2014 / Accepted: 2 December 2014 / Published online: 14 December 2014 \\ (C) The Author(s) 2014. This article is published with open access at Springerlink.com
}

\begin{abstract}
The Iron Age cemetery of Münsingen in Switzerland with 220 abundantly equipped burials marked a milestone for Iron Age research. The horizontal spread throughout the time of its occupancy laid the foundation for the chronology system of the Late Iron Age. Today, skulls of 77 individuals and some postcranial bones are still preserved. The aim of the study was to obtain information about diet, mobility and social stratification of the individuals. Stable isotope ratios of carbon, nitrogen and sulphur were analysed for 63 individuals. For all of them, $\mathrm{C}_{3}$ plants were found to be the staple food. There are significant differences between males and females in $\delta^{13} \mathrm{C}$ and $\delta^{15} \mathrm{~N}$ values. This points to a gender restriction in the access to animal protein with males probably having more access to meat and dairy products. Differences in $\delta^{15} \mathrm{~N}$ values were also observed for different age classes. $\delta^{34} \mathrm{~S}$ values indicate a terrestrial-based diet with no significant intake of marine or freshwater fish. Seven adults with enriched $\delta^{34} \mathrm{~S}$ values might have immigrated to Münsingen, four of which were found in the oldest part of the cemetery. Furthermore, possible changes of the vegetation are indicated by the more positive stable carbon ratios in the later phases. The results lead to the suggestion that especially
\end{abstract}

Electronic supplementary material The online version of this article (doi:10.1007/s12520-014-0221-4) contains supplementary material, which is available to authorized users.

N. Moghaddam $\cdot$ S. Lösch $(\bowtie)$

Department of Physical Anthropology, Institute of Forensic

Medicine, University of Bern, Sulgenauweg 40, 3007 Bern,

Switzerland

e-mail: sandra.loesch@irm.unibe.ch

F. Müller

Bernisches Historisches Museum, Bern, Switzerland

A. Hafner

Department of Prehistory, Institute of Archaeological Sciences,

University of Bern, Bern, Switzerland males buried with weapons might have played a special role in the Iron Age society.

Keywords Iron Age $\cdot$ Stable isotopes · Diet · Sex · Age · Grave goods

\section{Introduction}

The area surrounding Bern-north of the Alps and in the middle of the Swiss Plateau-provides the largest amount of skeletal material from the Late Iron Age throughout Switzerland. During the Iron Age, the Aare valley between the cities of Bern and Thun seems to have been part of a fairly developed settlement area that extended out to the west into the present-day Cantons Fribourg and Neuchâtel. Clusters in the geographical distribution of findings suggest two centres around the Belpberg including Belp, Münsingen, Rubigen and Niederwichtrach and around the Bern-Enge Peninsula which is encircled by the Aare River. Bern-Enge was probably the most important oppidum in Late Iron Age Switzerland (Müller 1998). Oppida are pre-urban settlements with defensive structures, and further sites of this type are known on the Swiss Plateau (Jud and Ulrich-Bochsler 2014).

The Late Iron Age burial site of Münsingen-Rain is situated in the Aare valley between Bern and Thun (Fig. 1). It was excavated in 1906 and first published by Jakob WiedmerStern (1908). Due to the size of the burial site, the welldocumented excavation and the abundance of grave goods Münsingen is an indispensable reference for chronological aspects of the Late Iron Age. As the burials were laid out from north to south, the 220 graves provide important archaeological information on horizontal stratigraphic dating (Müller 1998). The skeletal remains lay mostly supine and extended, without male, female or subadult groupings within the cemetery. In Fig. 2, graves are shown as numbers illustrating 
Fig. 1 Geographical location of Münsingen in the Canton of Bern (modified after Hodson 1968)

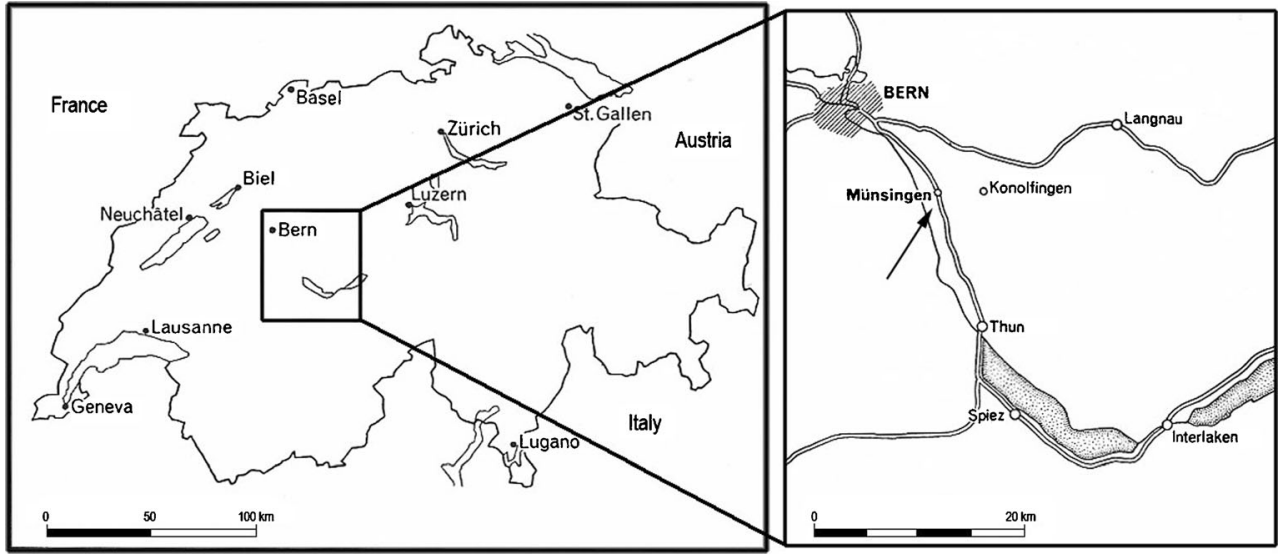

the horizontal spread from the earlier to the later phase. Further work on the chronology was conducted by the British archaeologist Frank R. Hodson (1968) with emphasis on the types of fibulae. The chronological phases for the Late Iron Age in Switzerland are defined as follows (Müller et al. 1999): La Tène $A$ from 450 to $400 \mathrm{BC}$ (LTA), La Tène $B$ from 400 to $260 \mathrm{BC}$ (LTB) and La Tène C from 260 to $150 \mathrm{BC}$ (LTC). The northern part of the site dates to the LTA period, and the last burials in the south date to the LTC period. The whole time span covers approximately 420 to $240 \mathrm{BC}$. The extraordinary abundance of grave goods and the continuity of the cemetery led to the assumption that the entire Münsingen population was of high social status. Additionally, the relatively long occupation time (from 420 to $240 \mathrm{BC}$ ) of the cemetery is exceptional (Müller et al. 2008).

In the past, the human remains and the archaeological findings from Münsingen were subject of many investigations (Alt et al. 2005; Kutterer and Alt 2008; Müller 1998; Scheeres et al. in press; Uerpmann 2005). Investigations also included biomolecular analysis to answer questions about genetic relations, but the analysed samples contained insufficient traces of DNA. Therefore, research on epigenetic characteristics and hereditary skull deformations was performed to assess possible biological relationships in the population (Kutterer and Alt 2008). While some skulls may appear to be deformed, even the anthropological measurements do not rule out the possibility that the deformation could be the result of taphonomical processes during burial time. The skull deformations as an indicator for genetic relationship therefore remain questionable.

The extensive archaeological material from the burial site of Münsingen also raised questions concerning migration and origin of the individuals. On the one hand, some subadults were buried with grave goods that were normally used for adult females. On the other hand, some burials contained incomplete jewellery sets or no grave goods at all (Sankot 1980). The position of all objects, especially fibulae, rings and bracelets, allowed a reconstruction of the attire of Iron Age women. Furthermore, the position of weapons such as swords and lances in male graves suggested how they might have been carried (Wyss et al. 2002). In some graves, traces of wooden coffins and stone settings were found (Müller et al. 2008).

\section{Stable isotopes}

Several studies on Iron Age human bones have been conducted, e.g. in Croatia (Lightfoot et al. 2012), the Czech Republic (Le Huray and Schutkowski 2005), Germany (Oelze et al. 2012), Great Britain (Jay and Richards 2006; Stevens et al. 2013), Greece (Papathanasiou et al. 2013), Russia (Murphy et al. 2013) and Sweden (Howcroft et al. 2012). So far, hardly any isotope analyses on human bones have been carried out in Switzerland, with the exception of Tütken et al. (2008). A short review of stable isotope values from some Iron Age burial sites in central Europe is shown in Table 1.

The analysis of the carbon stable isotope ratios in bone collagen sheds light on the input of $\mathrm{C}_{3}$ or $\mathrm{C}_{4}$ plants in the diet (DeNiro and Epstein 1978). Due to different photosynthetic pathways, $\mathrm{C}_{3}$ and $\mathrm{C}_{4}$ plants exhibit different $\delta^{13} \mathrm{C}$ values (Ambrose 1993; Hoefs 2009; Lee-Thorp et al. 1989). Stable carbon isotope ratios of $\mathrm{C}_{3}$ plants such as wheat and barley show values between -19 and $-35 \%$. $\delta^{13} \mathrm{C}$ values of $\mathrm{C}_{4}$ plants such as millet and amaranth are between -9 and $-15 \%$ (Ambrose 1993). In each trophic level of the food chain (prey to predator collagen), the $\delta^{13} \mathrm{C}\left({ }^{13} \mathrm{C} /{ }^{12} \mathrm{C}\right)$ value is enriched by + $1 \%$, whereas the fractionation factor between plants and bone collagen is $5 \%$ (Redfern et al. 2012).

Stable nitrogen isotopes $\delta{ }^{15} \mathrm{~N}\left({ }^{15} \mathrm{~N} /{ }^{14} \mathrm{~N}\right)$ in bone collagen reflect the intake of animal protein like meat and dairy products (Ambrose 1993; Stevens et al. 2010). The $\delta^{15} \mathrm{~N}$ value

Fig. 2 Grave numbers with illustration of horizontal spread in the greyscale $($ earlier phase $=$ black; later phase $=$ white $)$, possible immigrated individuals are marked in green (modified after Hodson 1968) 


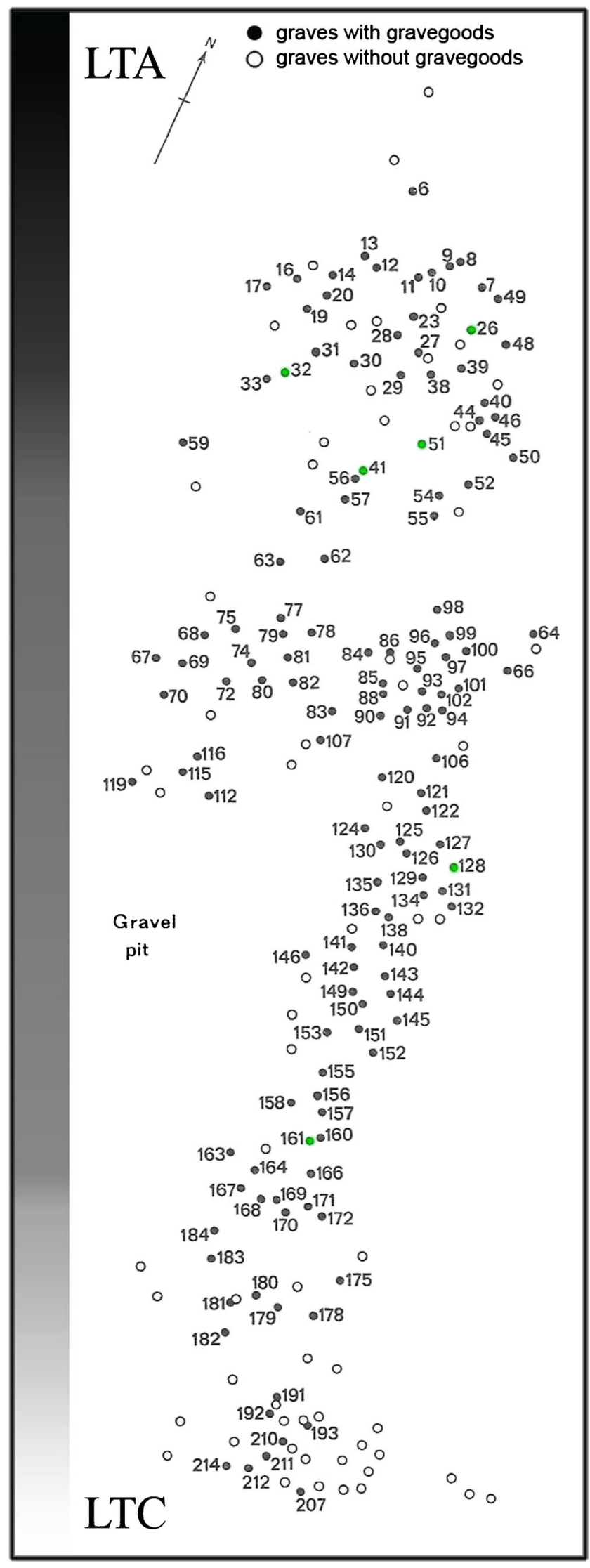

increases towards the top of the food chain in an ecosystem; hence, nitrogen stable isotope ratios provide information about the trophic level. Due to biological fractioning, the approximate shift between trophic levels is about +3 to $+5 \%$ in bone collagen (Bocherens and Drucker 2003; Hedges et al. 2007). Terrestrial plants generally have $4 \%$ lower $\delta^{15} \mathrm{~N}$ values than marine plants, and marine animals have higher $\delta{ }^{15} \mathrm{~N}$ values than terrestrial animals due to the trophic level effect with more trophic levels in marine than in terrestrial ecosystems. Therefore, nitrogen isotopes can not only be used to analyse the relative contribution of animal and plant food but also of terrestrial and marine resources (Schoeninger 1984).

A multiple isotopic approach with analysis of sulphur isotope ratios in addition to carbon and nitrogen provides more information about ancient populations' nutrition (Vika 2009). $\delta^{34} \mathrm{~S}\left({ }^{34} \mathrm{~S} /{ }^{32} \mathrm{~S}\right)$ in bone collagen is passed along the food chain with a small fractionation of approximately $-1 \%$. The $\delta^{34} \mathrm{~S}$ values in freshwater and terrestrial ecosystems range from -22 to $+22 \%$ (Oelze et al. 2012; Privat et al. 2007). Terrestrial mammals have $\delta^{34} \mathrm{~S}$ values lower than $+10 \%$, whereas organisms in marine ecosystems have values around $+20 \%$ o (Nehlich et al. 2012; Richards et al. 2003). In addition, variations in sulphur isotope data could provide information about migration of individuals. They vary in different geographical regions and geological conditions (Vika 2009). Until now, there are some publications about $\delta^{34} \mathrm{~S}$ in ancient bone collagen (Craig et al. 2006; Fornander et al. 2008; Hu et al. 2009; Kinaston et al. 2013; Nehlich et al. 2011; Nehlich et al. 2012; Oelze et al. 2012; Privat et al. 2007; Richards et al. 2003; Vika 2009).

For long bone cortex, a turnover rate of approximately 10 to 15 years is published (Hedges and Reynard 2007; Jay and Richards 2006), whereas the turnover rate for the skull is known to be approximately 50 years (Rummel et al. 2007). Therefore, the obtained signature reflects the diet during the individuals' last decades of life.

Stable isotope analyses $(\mathrm{C}, \mathrm{N}, \mathrm{S})$ were applied to reconstruct diet, social stratification and migration of individuals (Ambrose and Norr 1993; Lösch et al. 2006). The aim of this study was to reconstruct special diet restrictions of individuals from Münsingen including sex- or age-related variability of diet. A further goal was a chronological analysis and a correlation of the results with archaeological findings. In order to obtain information about an individual's social status, not only the presence or absence of grave goods can be used as an indicator (Härke 2000). Different studies already assessed status-related diet within a population by linking stable isotope values to archaeological data such as grave goods, location of graves or burial types (Jay and Richards 2006; Kinaston et al. 2013; Le BrasGoude et al. 2013; Le Huray and Schutkowski 2005; Linderholm et al. 2008). 
Table 1 Isotope data from human bones in Iron Age Europe

\begin{tabular}{|c|c|c|c|c|c|c|}
\hline \multirow[t]{2}{*}{ Study } & \multirow[t]{2}{*}{ Burial site } & \multirow[t]{2}{*}{ Period } & \multirow[t]{2}{*}{$n$} & \multicolumn{3}{|c|}{ Stable isotope values (mean and SD) } \\
\hline & & & & $\delta^{13} \mathrm{C}[\% 0]_{\mathrm{V}-\mathrm{PDB}}$ & $\delta^{15} \mathrm{~N}[\%]_{\mathrm{AIR}}$ & $\delta^{34} \mathrm{~S}[\%]_{\mathrm{V}-\mathrm{CDT}}$ \\
\hline This study & Münsingen $(\mathrm{CH})$ & Late Iron Age & 63 & $-19.5 \pm 0.7$ & $8.8 \pm 0.5$ & $1.0 \pm 2.2$ \\
\hline Jay and Richards (2006) & Wetwang Slack (UK) & Late Iron Age & 61 & $-20.5 \pm 0.3$ & $9.6 \pm 0.5$ & - \\
\hline Lightfoot et al. (2009) & Yarnton (UK) & Late Iron Age & 31 & $-20.1 \pm 0.3$ & $10.9 \pm 1.1$ & - \\
\hline Lightfoot et al. (2012) & Different sites in Croatia & Late Iron Age & 60 & $-19.0 \pm 0.8$ & $9.3 \pm 0.9$ & - \\
\hline Le Huray and Schutkowski (2005) & $\begin{array}{l}\text { Kutná Hora-Karlov, } \\
\text { Radiovesice I and II (CZ) }\end{array}$ & Late Iron Age & 87 & $-18.9 \pm 0.5$ & $9.8 \pm 0.6$ & - \\
\hline Knipper et al. (2014) & $\begin{array}{l}\text { Glauberg }(\mathrm{G}) \text { including } \\
\text { the "princely seat" }\end{array}$ & Early Iron Age & 24 & $-18.2 \pm 1.3$ & $9.5 \pm 1.8$ & - \\
\hline Oelze et al. (2012) & $\begin{array}{l}\text { Magdalenenberg }(G) \text { including } \\
\text { the "princely seat" }\end{array}$ & Early Iron Age & 50 & $-19.7 \pm 0.4$ & $9.6 \pm 0.8$ & $3.5 \pm 1.5(n=39)$ \\
\hline
\end{tabular}

\section{Material and methods}

From the original 220 abundantly equipped burials, the skulls of 77 individuals and some postcranial bones are still preserved today. For the statistical analysis, three different groups (LTA, LTB and LTC) were formed for the analysed individuals based on the relative chronology established by Stöckli (1975), Hodson (1998) and Jud (1998).

The remaining skeletal material from Münsingen is housed in the Archaeological Service of Bern, and five skulls are exhibited at the Natural History Museum in Bern, Switzerland. One individual is only represented by the mandible. Due to conservational reasons, samples of only 71 individuals were taken for stable isotope analyses. Bone material was obtained mostly from skulls and some long bones (online resource Table 2).

\section{Morphologic-anthropological investigation}

A morphologic-anthropological description of the bones was provided in a catalogue (Hug 1956). Due to methods that were developed in the last decades, the human remains were reinvestigated for this study. The individuals' sex and age-atdeath were determined using current methods (Ascádi and Nemeskéri 1970; Ferembach et al. 1979; Herrmann et al.

Table 2 Definition of the age classes

\begin{tabular}{ll}
\hline Age class & Years \\
\hline Infants I & $0-6$ \\
Infants II & $7-12$ \\
Juvenile & $13-20$ \\
Adult & $20-40$ \\
Mature & $40-60$ \\
Senile & $60+$ \\
\hline
\end{tabular}

1990; Rösing et al. 2007; Scheuer and Black 2000; Sjøvold 1988; Szilvássy 1988). For statistical tests, individuals were assigned to different age classes (Table 2).

\section{Stable isotope analysis}

Bone samples were cleaned with distilled water and ground to powder $(n=71)$. The collagen extraction followed the Ambrose (1993) and Longin (1971) procedure at the Department of Physical Anthropology at the University of Bern, Switzerland.

Five hundred-milligram bone powder was treated with $1 \mathrm{M}$ $\mathrm{HCl}$ to dissolve the bone mineral and then rinsed until neutral. To remove humic acids, the samples were treated with 0.125 $\mathrm{NaOH}$ and gelatinized in $0.001 \mathrm{M} \mathrm{HCl}$ at $90{ }^{\circ} \mathrm{C}$ for $17 \mathrm{~h}$. Then, the samples were filtered and freeze-dried. The lyophilized collagen was weighed in tin capsules $(3 \times)$, and the mean of three measurements was calculated. Stable isotope ratios of carbon $\left({ }^{13} \mathrm{C} /{ }^{12} \mathrm{C}\right)$, nitrogen $\left({ }^{15} \mathrm{~N} /{ }^{14} \mathrm{~N}\right)$ and sulphur $\left({ }^{34} \mathrm{~S} /{ }^{32} \mathrm{~S}\right)$ were analysed by isotope ratio mass spectrometry (IRMS at Isolab GmbH, Schweitenkirchen, Germany). All data are presented in $\delta$-notation in per mil (\%o) according to international standards for carbon (Vienna Pee Dee Belemnite, VPDB), nitrogen (Ambient Inhalable Reservoir, AIR) and sulphur (Canyon Diablo Troilite, CDT) (Fry 2006; Hoefs 2009; Schoeninger 1984). An internal standard was used for determination of the analytical error. It amounted to $\pm 0.1 \%$ for $\delta^{13} \mathrm{C}, \pm 0.2 \%$ for $\delta^{15} \mathrm{~N}$ and $\pm 0.3 \%$ for $\delta^{34} \mathrm{~S}$.

The collagen quality was verified as per Ambrose (1990), Ambrose (1993) and DeNiro (1985). Collagen with less than $1 \%$ in proportion to the dry weight and samples with a molar $\mathrm{C} / \mathrm{N}$ relation beyond a 2.9-3.6 range were not taken into consideration. Furthermore, $\% \mathrm{C}$ and $\% \mathrm{~N}$ values that strongly diverge from recent collagen values (C $43 \%$ and $\mathrm{N} 15-16 \%$ ) were not analysed. 


\section{Statistical tests}

All statistical tests were performed with SPSS Statistics 20. The robust $T$ test for independent groups (two parameters) and the one-way ANOVA (three or more parameters) were used to determine significant differences between groups. Additionally, the non-parametric Mann-Whitney $U$ test (two parameters) and Kruskal-Wallis test (three or more parameters) for independent samples were used due to the small sample size as normality is not given for all groups (Fagerland 2012). The level of significance is indicated with superscript stars on the $p$ values: $p \leq 0.05\left(^{*}\right) ; p \leq 0.01(* *)$; and $p \leq 0.001(* * *)$.

\section{Results}

After applying the quality criteria, 63 of 71 collagen samples remained for the analysis of stable carbon, nitrogen and sulphur isotopes (27 males, 29 females, 7 infants). All data will be shown with individual numbers because some graves contained more than one individual. For corresponding grave numbers, see online resource Table 2.

All $\delta^{34} \mathrm{~S}$ values were evaluated for this study, except the samples that were excluded due to the aforementioned collagen quality criteria. Descriptive statistics for carbon, nitrogen and sulphur stable isotope ratios for all individuals $(n=63)$ are shown in Table 3.

$\delta^{13} \mathrm{C}$ values range from -20.8 to $-17.4 \%$ (mean $-19.5 \%$; standard deviation (SD) $0.7 \%$ ), those of $\delta^{15} \mathrm{~N}$ range from 7.6 to $10.2 \%$ (mean $8.8 \%$; SD 0.5 ) and $\delta^{34} \mathrm{~S}$ values range from -2.3 to $7.6 \%$ (mean $1.0 \%$; SD $2.2 \%$ ).

The one-way ANOVA showed significant differences between the $\delta^{13} \mathrm{C}(p=0.022 *)$ and $\delta^{15} \mathrm{~N}$ mean values $(p=$ $\left.0.005^{* *}\right)$ of males, females and infants but no significant difference for $\delta^{34} \mathrm{~S}$ mean values $(p=0.198)$. The infant I and II age groups were excluded by testing only males and females. In this case, the $T$ test for independent groups revealed significant differences between $\delta^{13} \mathrm{C}$ and $\delta^{15} \mathrm{~N}$ mean values $(p$ for $\left.\delta^{13} \mathrm{C}=0.007^{* *}, \delta^{15} \mathrm{~N}=0.006^{* *}, \delta^{34} \mathrm{~S}=0.686\right)$. Non- parametric tests showed also significant differences between the sexes (Table 4).

No significant difference between the different age classes (infants I and II, juvenile, adult, mature, senile) can be observed (one-way ANOVA). Non-parametric Kruskal-Wallis test showed significant differences in the $\delta^{15} \mathrm{~N}$ values between the different age classes $\left(p=0.030^{*}\right)$.

Forty-three of 63 individuals could be assigned to a chronological group (Table 5). For the LTB period, no infants were available for analysis. One-way ANOVA revealed no significant differences, while the $\delta^{13} \mathrm{C}$ values are significant different by using the non-parametric Kruskal-Wallis test for independent groups (Table 4).

The analysed samples were also subdivided into two groups according to the presence or absence of grave goods (online resource Table 2). Forty-seven individuals out of 63 were found with grave goods and 16 without (Jud 1998). The $T$ test and the non-parametric Mann-Whitney $U$ test for independent groups revealed no significant differences between these two groups (Table 4).

\section{Discussion}

Limitation of the study

It has to be mentioned that no animal bones from Münsingen or close by Iron Age burial sites were available for stable isotope analysis. The analysis of faunal remains can provide important information on the general status of the whole population, so human-faunal trophic level should be taken into consideration. Differences in the stable isotope values could be the result of various environmental factors and/or different methods of animal husbandry (Stevens and Hedges 2004; Ugan and Coltrain 2011). Therefore, a comparison of the diet of the Münsingen population with published data from other geographical regions is hardly possible. There are a few faunal remains from the Iron Age burial site of Engehalbinsel, but they are not dated yet. These remains were not available during the analysis of the Münsingen material, but they are

Table 3 Descriptive statistics for carbon, nitrogen and sulphur stable isotope ratios ( $n=63$, mean, standard deviation, median, minimum, maximum)

\begin{tabular}{|c|c|c|c|c|c|c|c|c|c|c|c|c|c|c|c|c|}
\hline & \multicolumn{6}{|c|}{$\delta^{13} \mathrm{C}[\%]_{\mathrm{V}-\mathrm{PDB}}$} & \multicolumn{5}{|c|}{$\delta^{15} \mathrm{~N}[\%]_{\mathrm{AIR}}$} & \multicolumn{5}{|c|}{$\delta^{34} \mathrm{~S}[\% 0]_{\mathrm{V}-\mathrm{CDT}}$} \\
\hline & $n$ & Mean & SD & Median & Min & Max & Mean & $\mathrm{SD}$ & Median & Min & Max & Mean & SD & Median & Min & Max \\
\hline Male & 27 & -19.7 & 0.6 & -19.9 & -20.8 & -18.5 & 9.0 & 0.5 & 9.0 & 7.6 & 10.2 & 1.3 & 2.4 & 0.8 & -2.3 & 7.6 \\
\hline Female & 29 & -19.2 & 0.7 & -19.2 & -20.5 & -17.4 & 8.6 & 0.5 & 8.7 & 7.6 & 9.5 & 1.0 & 2.1 & 0.3 & -1.2 & 6.4 \\
\hline Infants I and II & 7 & -19.6 & 0.6 & -19.3 & -20.5 & -19.0 & 8.5 & 0.3 & 8.6 & 7.9 & 8.8 & -0.4 & 1.4 & -0.8 & -1.7 & 1.6 \\
\hline Total & 63 & -19.5 & 0.7 & -19.6 & -20.8 & -17.4 & 8.8 & 0.5 & 8.8 & 7.6 & 10.2 & 1.0 & 2.2 & 0.4 & -2.3 & 7.6 \\
\hline
\end{tabular}

$S D$ standard deviation 
Table 4 Results of statistical tests

\begin{tabular}{|c|c|c|c|c|}
\hline Different groups & $n$ & Variables & $\begin{array}{l}T \text { test or one-way } \\
\text { ANOVA }(p)\end{array}$ & $\begin{array}{l}\text { Mann-Whitney } U \text { or } \\
\text { Kruskal-Wallis test }(p)\end{array}$ \\
\hline \multirow[t]{3}{*}{ Male vs. female vs. infants } & \multirow[t]{3}{*}{$27 ; 29 ; 7$} & $\delta^{13} \mathrm{C}$ & $0.022 *$ & $0.035^{*}$ \\
\hline & & $\delta^{15} \mathrm{~N}$ & $0.005 * *$ & $0.003 * *$ \\
\hline & & $\delta^{34} \mathrm{~S}$ & 0.198 & 0.168 \\
\hline \multirow[t]{3}{*}{ Male vs. female } & \multirow[t]{3}{*}{$27 ; 29$} & $\delta^{13} \mathrm{C}$ & $0.007 * *$ & $0.011^{*}$ \\
\hline & & $\delta^{15} \mathrm{~N}$ & $0.006^{* *}$ & $0.006^{* *}$ \\
\hline & & $\delta^{34} \mathrm{~S}$ & 0.686 & 0.605 \\
\hline \multirow[t]{3}{*}{ Male vs. infants } & \multirow[t]{3}{*}{$27 ; 7$} & $\delta^{13} \mathrm{C}$ & 0.554 & 0.617 \\
\hline & & $\delta^{15} \mathrm{~N}$ & $0.012 *$ & $0.004^{* *}$ \\
\hline & & $\delta^{34} \mathrm{~S}$ & 0.090 & 0.081 \\
\hline \multirow[t]{3}{*}{ Females vs. infants } & \multirow[t]{3}{*}{$29 ; 7$} & $\delta^{13} \mathrm{C}$ & 0.258 & 0.287 \\
\hline & & $\delta^{15} \mathrm{~N}$ & 0.476 & 0.387 \\
\hline & & $\delta^{34} \mathrm{~S}$ & 0.950 & 0.094 \\
\hline \multirow{3}{*}{$\begin{array}{l}\text { Age classes (infants I, infants II, juvenile, } \\
\text { adult, mature, senile) }\end{array}$} & \multirow[t]{3}{*}{$1 ; 6 ; 3 ; 32 ; 12 ; 9$} & $\delta^{13} \mathrm{C}$ & 0.175 & 0.163 \\
\hline & & $\delta^{15} \mathrm{~N}$ & 0.083 & $0.030^{*}$ \\
\hline & & $\delta^{34} \mathrm{~S}$ & 0.367 & 0.157 \\
\hline \multirow[t]{3}{*}{ LTA vs. LTB vs. LTC } & \multirow[t]{3}{*}{$14 ; 21 ; 8$} & $\delta^{13} \mathrm{C}$ & 0.055 & $0.035^{*}$ \\
\hline & & $\delta^{15} \mathrm{~N}$ & 0.809 & 0.877 \\
\hline & & $\delta^{34} \mathrm{~S}$ & 0.292 & 0.251 \\
\hline \multirow[t]{3}{*}{ With vs. without grave goods } & \multirow[t]{3}{*}{$47 ; 16$} & $\delta^{13} \mathrm{C}$ & 0.568 & 0.548 \\
\hline & & $\delta^{15} \mathrm{~N}$ & 0.384 & 0.248 \\
\hline & & $\delta^{34} \mathrm{~S}$ & 0.887 & 0.850 \\
\hline \multirow[t]{3}{*}{ All individuals vs. armed males } & \multirow[t]{3}{*}{$54 ; 9$} & $\delta^{13} \mathrm{C}$ & 0.209 & 0.197 \\
\hline & & $\delta^{15} \mathrm{~N}$ & $0.014^{*}$ & $0.009^{* *}$ \\
\hline & & $\delta^{34} \mathrm{~S}$ & 0.291 & 0.326 \\
\hline
\end{tabular}

$T$ test for independent groups (two parameters) and one-way ANOVA (three or more parameters) were performed. Additionally, Mann-Whitney $U$ test (two parameters) and non-parametric Kruskal-Wallis test (three or more parameters) for independent samples were used due to the small sample size ${ }^{*} p \leq 0.05,{ }^{* *} p \leq 0.01, * * * p \leq 0.001$

subject of ongoing research and will be presented in future work.

Entire population - differences in sex and age

For a comparison of male and female data, the infant I and II age groups were excluded. The observed carbon isotope ratios of all individuals indicate that the subsistence bases in Münsingen were $\mathrm{C}_{3}$ plants such as wheat and barley. These cereals were not only used for solid food. In Hochdorf,

Table 5 Numbers of individuals assigned to the different time phases

\begin{tabular}{llllll}
\hline & & Male & Female & Infants I and II & Total \\
\hline Time period & LTA & 4 & 6 & 4 & 14 \\
& LTB & 11 & 10 & 0 & 21 \\
& LTC & 2 & 6 & 0 & 8 \\
\multirow{5}{*}{ Total } & No dating & 10 & 7 & 3 & 20 \\
& & 27 & 29 & 7 & 63 \\
\hline
\end{tabular}

Germany, there is evidence of beer brewing during the early Iron Age (Stika 1996; Stika 2011). Palaeobotanical analysis showed that wheat and barley were the most common cereals in central Europe during the Iron Age. $\mathrm{C}_{4}$ plants were also found in the Iron Age Alpine region and southeastern France (Bouby et al. 2011; Jacomet and Jacquat 1999; Schmidl et al. 2007). However, the data in this study give no indication of a significant intake of $\mathrm{C}_{4}$ plants, although males in Münsingen show a more negative $\delta^{13} \mathrm{C}$ mean than females (Table 3$) . \delta^{13} \mathrm{C}$ values more positive than $-18 \%$ lead to the suggestion of $\mathrm{C}_{4}$ plant consumption (Le Huray and Schutkowski 2005), as the presence of millet is known since at least the third millennium BC (Hunt et al. 2008; Motuzaite-Matuzeviciute et al. 2013). Lightfoot et al. (2012) suggest a minor consumption of millet in Iron Age Croatia $(n=60)$. Le Huray and Schutkowski (2005) also published more positive $\delta^{13} \mathrm{C}$ (mean $-18.9 \pm 0.5$ \%) for different Late Iron Age burial sites in the Czech Republic. They conclude that the more positive $\delta^{13} \mathrm{C}$ values may reflect some contribution of $\mathrm{C}_{4}$ plants for at least some individuals. However, an increase of $\delta^{13} \mathrm{C}$ values could also 
indicate a higher consumption of, e.g. seeds, fruits and roots (Cernusak et al. 2009). In Münsingen, the values of one female (A70) and possibly those of two other females (A102, A110) also point to an occasional consumption of $\mathrm{C}_{4}$ plants. The slightly depleted $\delta^{13} \mathrm{C}$ values of the males could also indicate a higher intake of (animal) products from boreal environments. Species that are endemic to forested habitats exhibit lower $\delta^{13} \mathrm{C}$ values than those from open land spaces (Bonafini et al. 2013; Drucker et al. 2008; Stevens et al. 2006). Even though the proportion of wild animal bones in settlements from this time and region is less than $2 \%$ and therefore comparatively low (Schibler et al. 1999), it cannot be excluded that men spent more time in the forest and used its food resources more frequently. Eating these foods on the spot may also explain the largely absent wild animal bones in the settlement waste. Hunting or military excursions to neighbouring regions that lasted several days or weeks are a possible hypothesis. Likewise, the enriched $\delta^{13} \mathrm{C}$ values in females could be the result of them mostly staying in the settlement and subsisting on domesticated animal resources.

The $\delta^{15} \mathrm{~N}$ values show differences between females and males, with males having significantly higher values than females (Table 4). This leads to the suggestion that there might have been gender restrictions in the access to animal proteins (meat and dairy products) and that males consumed more animal proteins. These differences in diet could be related to a gender-specific division of labour in which males were responsible for meat preparation. A more plausible explanation for the population of Münsingen is a higher social rank of male individuals that was accompanied by better access to animal protein. Even though there are statistically significant differences between males and females, it must be kept in mind that these differences are small (Fig. 3). This result is in line with past findings of animal bones only in male graves, even though there were also females with "high class" grave goods like the adult female A114 (Jud 1998).

The only senile female (A66) has a high $\delta^{15} \mathrm{~N}$ value of $9.45 \%$ compared to the rest of the group as well. According to the illustrations of Wiedmer-Stern (1908),

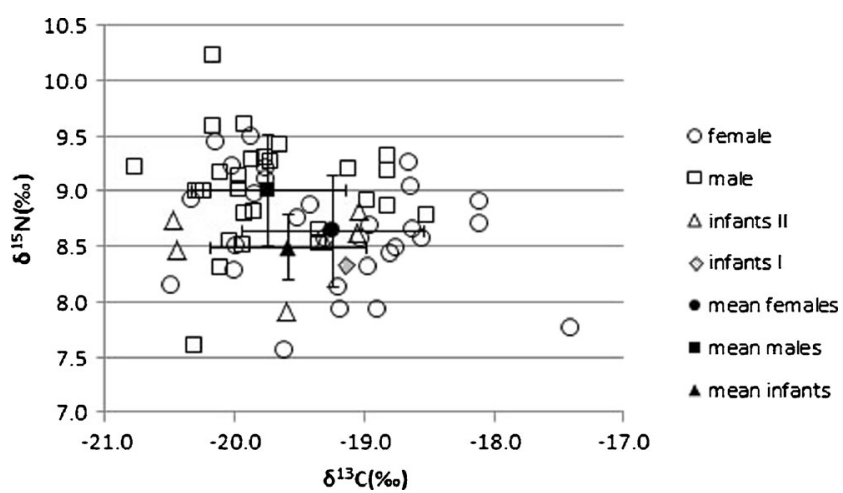

Fig. 3 Plot of $\delta^{13} \mathrm{C}$ and $\delta^{15} \mathrm{~N}$ values for Münsingen human bone collagen samples with mean values and standard error bars $(n=63)$ this female can be dated to the LTA/LTB period, and no grave goods were found in this grave.

$\delta^{34} \mathrm{~S}$ values indicate a strictly terrestrial diet with no intake of marine food. This is supported by the fact that no fish bones were recovered from this site (Jud 1998). It should be mentioned that it is not unusual to have no fish bones on a burial site due to poor preservation or excavation techniques used in the past. However, Dobney and Ervynck (2007) mention cultural or spiritual factors as a possible explanation for this phenomenon. In either case, access to marine food is naturally not expected for Münsingen. The stable isotope ratios do not provide evidence of an increased consumption of freshwater fish, even though a wide variability of the isotope values has to be considered (Katzenberg et al. 2012; Katzenberg 1999). It remains unclear why freshwater fish was apparently not used as an important resource even though the Aare River is nearby. Similarly, no exploitation of freshwater resources is suggested for the Iron Age burial site in Yarnton which is also close to a river (Lightfoot et al. 2009). It is assumed that marine fish was not often used as food resource in the British Iron Age (Dobney and Ervynck 2007). The burial site Wetwang Slack is nowadays located approximately $25 \mathrm{~km}$ from the coast, and the authors suggest a diet without marine foods (Jay and Richards 2006). Likewise, investigations of diet in Iron Age Croatia found no evidence of significant marine protein consumption in spite of the analysed burial sites being close to the coast (Lightfoot et al. 2012).

There are no significant differences between the age groups for $\delta^{13} \mathrm{C}$ and $\delta^{34} \mathrm{~S}$ values. Lightfoot et al. (2009) investigated Iron Age individuals $(n=31)$ from Yarnton, UK and found the highest $\delta^{15} \mathrm{~N}$ values in infants $(<3 \mathrm{a})$. This result derives from a higher trophic level due to breastfeeding. Nursing babies consume mother's milk which is enriched with ${ }^{15} \mathrm{~N}$ (Bourbou et al. 2013; Burt 2013; Fuller et al. 2006; Katzenberg 2008; Katzenberg et al. 1996). In this study, only one child (A50) aged 3 to 5 years could be analysed for stable isotope ratios. Compared to other individuals, the $\delta^{15} \mathrm{~N}$ value was relatively low $(8.34 \%$ ). The infants in Münsingen show no breastfeeding signal. Due to the lack of infant I and the small number of infant II, the weaning time cannot be narrowed down. After excluding all infants, still no significant difference of $\delta^{15} \mathrm{~N}$ between the different age classes can be detected (one-way ANOVA; $p=0.080$ ). However, there is a tendency of senile individuals to be enriched with ${ }^{15} \mathrm{~N}$ by using the one-way ANOVA $(p=0.083)$ and even a significant difference by testing with non-parametric Kruskal-Wallis test $\left(p=0.030^{*}\right)$. This might suggest that the oldest individuals had a higher proportion of animal protein in their diet. This tendency stands in contrast to results from Iron Age Yarnton where the opposite was observed (Lightfoot et al. 2009). Prowse et al. (2005) had similar results in their analysis of Imperial Roman human remains from the necropolis of Isola Sacra, Italy. Their results show a positive correlation between age and $\delta^{15} \mathrm{~N}$. The data of Prowse et al. (2005) indicate that 
subadults consumed a more herbivorous diet. They suggest that maybe a suboptimal diet might have led to their early death. This could also be possible for Münsingen. However, it remains questionable if senile individuals lived longer because of an increased consumption of animal proteins or if older individuals had a higher social status in the community. For the comparison of age classes, it should be kept in mind that the determination of the age-at-death was based on morphological features on the skulls. Especially for adult and older individuals, this might have led to some uncertainties that could have influenced the statistical analysis. Manuring is also a possibility that has to be considered with regard to variations in stable nitrogen values between different burial sites (Bogaard et al. 2007). Human diets with a high component of manured grain lead to elevated nitrogen values and could therefore also be interpreted as a diet with a high amount of animal protein. This has to be considered for the Iron Age as there manuring practices were found in prehistory as well (Guttmann et al. 2006; Nielsen and Kristiansen 2014).

\section{Mobility}

The $\delta^{34} \mathrm{~S}$ values of all infants (and juveniles) range between -2 and $2 \%$. There is little fractionation of sulphur isotopes through food chains, and therefore, $\delta^{34} \mathrm{~S}$ values of bone collagen reflect the local geological sulphate (Richards et al. 2001). Assuming that young individuals had few opportunities to travel, their $\delta^{34} \mathrm{~S}$ signal might best represent the local sulphur signal. Males and females with enriched $\delta^{34} \mathrm{~S}$ could have lived at or near coastal areas at some point in their life (Fig. 4). Due to the so-called sea spray effect, the $\delta^{34} \mathrm{~S}$ values might also reflect the proximity of the food source to the sea (Richards et al. 2003). Three males (A57, A62 and A65) and four females (A60, A70, A88 and A108) show enriched $\delta^{34} S$ values above $4 \%$, and a migration to Münsingen could be possible for these individuals (Fig. 2, marked in green). Four of them (A57, A60, A62 and A70), two males and two females, were buried in the oldest part (LTA) and might belong to the "founder generation". The dating for two other individuals (A65 and A 88) is uncertain, and one

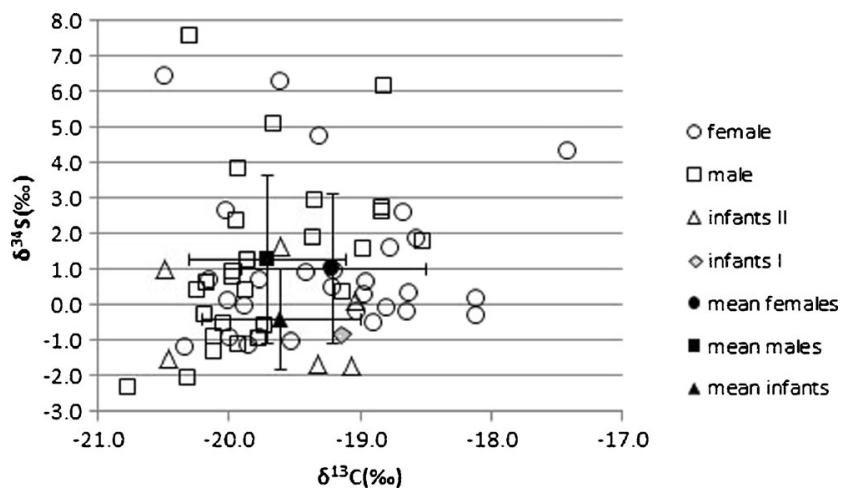

Fig. 4 Plot of $\delta^{13} \mathrm{C}$ and $\delta^{34} \mathrm{~S}$ for Münsingen human bone collagen samples with mean values and standard error bars $(n=63)$ individual (A108) dates to the LTC period. One female aged 30 50 years (A70) additionally shows an extraordinarily high $\delta^{13} \mathrm{C}$ value $\left(-17.4 \%\right.$ ) and a relatively low $\delta^{15} \mathrm{~N}$ value $(7.8 \%)$. This female with a sulphur value of $4.4 \%$ could either have had a different diet than the others or might have migrated to Münsingen from another region with more access to $\mathrm{C}_{4}$ plants. This woman was buried in the northern part (LTA to LTB) of the cemetery. Investigations of strontium and oxygen isotope ratios by Scheeres et al. (in press) also show minor mobility of the Münsingen population. For a better comparison, their data are used as individual numbers (grave numbers were used in the original publication). They analysed tooth enamel of 38 individuals for strontium isotope ratios and 34 individuals for oxygen isotope ratios. Their results indicate that two females from the LTA period (A43 and A60) immigrated to Münsingen. This is in accordance with the result for individual A60 in this study. Unfortunately, the possibly immigrated individuals A62, A65, A70, A88 and A108 in this study were not analysed by Scheeres et al. (in press). The authors suggest that five individuals (A43, A60, A67, A85 and A103) were not local due to the strontium and oxygen isotope values. The individuals A43, A67 and A103 could not be analysed in this study due to collagen quality criteria. Individual A85 shows no evidence of migration based on the stable sulphur value. Like what Scheeres et al. (in press) stated, this study could give an additional hint that the founder population in Münsingen mainly consisted of an existing local community to which both males and females immigrated from elsewhere. Whether the structure of the Münsingen population was patrilocal or matrilocal cannot be ascertained by the presented stable isotope values.

\section{Chronology}

Due to the clear horizontal spread of the Münsingen burials and the good documentation, 43 out of 63 individuals could be assigned to a chronological group. No significant differences of stable nitrogen and sulphur isotope values between three chronological periods of the Münsingen burials were found (Table 4). However, stable carbon isotope ratios show significant more positive values in later phases of the burial site compared to earlier phases (non-parametric Kruskal-Wallis test; $p=$ $\left.0.035^{*}\right)$. This could indicate minor changes in vegetation and crops which is possible due to climate changes during the Iron Age in central Europe. Climate reconstructions from sediments of Lake Silvaplana in Switzerland indicate warmer trends in the Late Iron Age (Stewart et al. 2011). Palaeoglaciological analysis of fluctuations of the Great Aletsch glacier (Valais Alps) shows a minimum length of the glacier tongue between $200 \mathrm{BC}$ and $50 \mathrm{AD}$ for the Late Iron Age (Holzhauser et al. 2005). Due to postponed effect of climate on the glacier, a time lag of a few decades can be assumed. Warmer climate probably would have led to increased growth of $\mathrm{C}_{4}$ plants such as millet which prefer warmer ecosystems (Ehleringer et al. 1991; Satrapová et al. 2013). This 
could be a possible hypothesis for the more positive $\delta^{13} \mathrm{C}$ in the LTC period. While there is no evidence for a significant $\mathrm{C}_{4}$ plant intake in Münsingen, a minor consumption of, e.g. millet in the later phases has to be considered.

\section{Grave goods}

The burials varied in their content of archaeological findings from those with many grave goods to those with none (online resource Table 2). Some grave goods such as weapons, meat and gold finger rings were only given to adult and older males. No significant differences between the individuals with and those without grave goods were obtained. Nevertheless, in 18 male burials, items of weaponry were found, particularly swords in 12 male burials but also lances and shields (Jud 1998). Weapons, especially swords, are usually considered to be prestige grave goods and a symbol for a higher status (Linderholm et al. 2008). Ten of the "armed" males from Münsingen were available for the stable isotope analysis, but A47 was excluded due to collagen quality criteria. The $\delta^{13} \mathrm{C}$ and $\delta^{34} \mathrm{~S}$ values of the remaining nine males (A58, A72, A78, A80, A81, A84, A95, A100 and A117) show no significant differences in comparison to all other individuals. But the $\delta^{15} \mathrm{~N}$ values show significant differences with higher values in the males buried with weapons (Table 4). These results indicate increased access to animal protein for the "armed" males. Analysis of Iron Age populations in Bohemia also showed different dietary patterns with higher $\delta^{15} \mathrm{~N}$ values for some male individuals buried with weapons (Le Huray and Schutkowski 2005). The $\delta^{34} \mathrm{~S}$ values of these nine males are very heterogenic and vary between -2.0 and $2.7 \%$. None of them indicate a possible immigration to Münsingen.

Meat as a possible prestige grave good was probably given exclusively to males as it was only found within male graves (Jud 1998). Four individuals (A72, A75, A78 and A80) with meat as grave goods were available for stable isotope analysis (see online resource Table 2, marked with circles). The adult male A80 shows the highest $\delta^{15} \mathrm{~N}$ value with $10.23 \%$. This individual was buried with weapons and meat. The high $\delta^{15} \mathrm{~N}$ value strongly suggests a diet with more animal protein than the other individuals. He might have played a special role in the society, and it is possible that he had privileges due to a high status. Oelze et al. (2012) published isotope values of 50 individuals from Early Iron Age Magdalenenberg, Germany. The Magdalenenberg tumulus contained a "princely burial" which was represented only by a long bone due to early grave robbing and some other adult male individuals which were characterised as high status "warriors". They also showed a different diet than the other individuals in the tumulus. Iron Age populations from the Czech Republic (Le Huray and Schutkowski 2005) and burial sites in Germany (Knipper et al. 2014) show evidence of a different diet of males buried with weapons, as well. These data in summary indicate a higher social status for the Iron Age "warrior" burials assuming that the availability of meat or dairy products was probably restricted.

Furthermore, it has to be mentioned that isotopic variations in Europe are not only caused by cultural, biological and environmental factors but probably also correspond to regional differences in climate (Van Klinken and Hedges 2000). For this reason, comparisons of stable isotope values from different regions in Europe have to be carried out carefully.

\section{Conclusion}

The carbon isotope ratios indicate that the subsistence base of all individuals in Münsingen were $\mathrm{C}_{3}$ plants. The $\delta^{13} \mathrm{C}$ and $\delta^{15} \mathrm{~N}$ values show significant differences between the sexes. There might have been a gender restriction in the access to food, especially animal proteins. The data also indicate a tendency towards a different diet of adults and seniles, with the diet of the latter probably containing more animal protein. $\delta^{34} \mathrm{~S}$ values show no significant intake of marine and freshwater fish for most of the individuals. The results also indicate that the founder population of Münsingen consisted mainly of an existing local community to which a few individuals - two females and two males-immigrated. A trend in $\delta^{13} \mathrm{C}$ values of the different chronological phases leads to the suggestion that a change in diet took place in the later phases. A possible explanation could be a climate change during the occupancy time of the cemetery (LTA to LTC) that caused a change in vegetation. No differences between the individuals with grave goods and those without could be observed. However, the data lead to the suggestion that males buried with weapons might have played a special role in the Iron Age society of Münsingen.

Acknowledgments We are very grateful for the helpful comments of the reviewers. We thank Andreas Rossmann for stable isotope measurements, Christine Cooper for editing, Marc Nussbaumer and the Archaeological Service of the Canton of Bern for support. We also thank Silke Schleiss for assistance in the laboratory, Matthias Dömötör for image editing and Domenic Rüttimann for helpful comments. This project was funded by the Swiss National Science Foundation (CR13I3_149589).

Open Access This article is distributed under the terms of the Creative Commons Attribution License which permits any use, distribution, and reproduction in any medium, provided the original author(s) and the source are credited.

\section{References}

Alt KW, Jud P, Müller F, Nicklisch N, Uerpmann A, Vach W (2005) Biologische Verwandtschaft und soziale Struktur im Latènezeitlichen Gräberfeld von Münsingen-Rain. Jahrbuch RGZM 52:157-210 
Ambrose SH (1990) Preparation and characterization of bone and tooth collagen for isotopic analysis. J Archaeol Sci 17:431-451

Ambrose SH (1993) Isotopic analysis of paleodiets: methodological and interpretive considerations. In: Sandford MK (ed) Investigations of ancient human tissue: chemical analyses in anthropology. Gordon and Breach Science Publishers, Langhorne, PA, pp 59-130

Ambrose SH, Norr L (1993) Experimental evidence for the relationship of the carbon isotope ratios of whole diet and dietary protein to those of bone collagen and carbonate. In: Lambert JB, Grupe G (eds) Prehistoric human bone: archaeology at the molecular level. Springer, Berlin, pp 1-37

Ascádi G, Nemeskéri I (1970) History of human lifespan and mortality. Academiai Kiado, Budapest

Bocherens H, Drucker D (2003) Trophic level isotopic enrichment of carbon and nitrogen in bone collagen: case studies from recent and ancient terrestrial ecosystems. Int J Osteoarchaeol 13:46-53

Bogaard A, Heaton THE, Poulton P, Merbach I (2007) The impact of manuring on nitrogen isotope ratios in cereals: archaeological implications for reconstruction of diet and crop management practices. J Archaeol Sci 34:335-343. doi:10.1016/j.jas.2006.04.009

Bonafini M, Pellegrini M, Ditchfield P, Pollard AM (2013) Investigation of the 'canopy effect' in the isotope ecology of temperate woodlands. J Archaeol Sci 40:3926-3935. doi:10.1016/j.jas.2013.03.028

Bouby L, Boissinot P, Marinval P (2011) Never mind the bottle. Archaeobotanical evidence of beer-brewing in Mediterranean France and the consumption of alcoholic beverages during the 5 th century BC. Hum Ecol 39:351-360

Bourbou C, Fuller BT, Garvie-Lok SJ, Richards MP (2013) Nursing mothers and feeding bottles: reconstructing breastfeeding and weaning patterns in Greek Byzantine populations (6th-15th centuries $\mathrm{AD}$ ) using carbon and nitrogen stable isotope ratios. $\mathrm{J}$ Archaeol Sci 40:3903-3913

Burt NM (2013) Stable isotope ratio analysis of breastfeeding and weaning practices of children from medieval Fishergate House York. UK Am J Phys Anthropol 152:407-416. doi:10.1002/ajpa. 22370

Cernusak LA et al (2009) Viewpoint: why are non-photosynthetic tissues generally $\mathrm{C}-13$ enriched compared with leaves in C-3 plants? Review and synthesis of current hypotheses. Funct Plant Biol 36: 199-213. doi:10.1071/Fp08216

Craig OE, Ross R, Andersen SH, Milner N, Bailey GN (2006) Focus: sulphur isotope variation in archaeological marine fauna from northern Europe. J Archaeol Sci 33:1642-1646

DeNiro MJ (1985) Postmortem preservation and alteration of in vivo bone-collagen isotope ratios in relation to paleodietary reconstruction. Nature 317:806-809

DeNiro MJ, Epstein S (1978) Influence of diet on the distribution of carbon isotopes in animals. Geochimica et Cosmochimica Acta 42: 495-506

Dobney K, Ervynck A (2007) To fish or not to fish? Evidence for the possible avoidance of fish consumption during the Iron Age around the North Sea. In: Haselgrove C, Moore T (eds) The Later Iron Age in Britain and beyond. Oxford Books, Oxford, pp 403-418

Drucker DG, Bridault A, Hobson KA, Szuma E, Bocherens H (2008) Can carbon-13 in large herbivores reflect the canopy effect in temperate and boreal ecosystems? Evidence from modern and ancient ungulates. Palaeogeogr Palaeocl 266:69-82. doi:10.1016/j.palaeo.2008. 03.020

Ehleringer JR, Sage RF, Flanagan LB, Pearcy RW (1991) Climate change and the evolution of C4 photosynthesis. Trends Ecol Evol 6:95-99. doi:10.1016/0169-5347(91)90183-X

Fagerland MW (2012) T-tests, non-parametric tests, and large studies - a paradox of statistical practice? Bmc Med Res Methodol 12:78. doi: 10.1186/1471-2288-12-78

Ferembach D, Schwidetzky I, Stloukal M (1979) Recommendations for age and sex diagnoses of skeletons. B Mem Soc Anthro Par 6:7-45
Fornander E, Eriksson G, Liden K (2008) Wild at heart: approaching pitted ware identity, economy and cosmology through stable isotopes in skeletal material from the Neolithic site Korsnas in Eastern Central Sweden. J Anthropol Archaeol 27:281-297

Fry B (2006) Stable isotope ecology. Springer Science and Business Media, LLC New York

Fuller BT, Molleson TI, Harris DA, Gilmour LT, Hedges REM (2006) Isotopic evidence for breastfeeding and possible adult dietary differences from Late/Sub-Roman Britain. Am J Phys Anthropol 129: $45-54$

Guttmann EB, Simpson IA, Davidson DA, Dockrill SJ (2006) The management of arable land from prehistory to the present: case studies from the northern isles of Scotland. Geoarchaeology 21: 61-92. doi:10.1002/Gea.20089

Härke H (2000) Social analysis of mortuary evidence in German protohistoric archaeology. J Anthropol Archaeol 19:369-384

Hedges RE, Clement JG, Thomas CD, O'Connell TC (2007) Collagen turnover in the adult femoral mid-shaft: modeled from anthropogenic radiocarbon tracer measurements. Am J Phys Anthropol 133:808816. doi:10.1002/ajpa.20598

Hedges REM, Reynard LM (2007) Nitrogen isotopes and the trophic level of humans in archaeology. J Archaeol Sci 34:1240-1251

Herrmann B, Grupe G, Hummel S, Piepenbrink H, Schutkowski H (1990) Prähistorische Anthropologie. Leitfaden der Feldund Labormethoden Springer Verlag Berlin, Heidelberg, New York

Hodson FR (1968) The la Tène Cemetery at Münsingen-Rain. Acta Bernensia V. Verlag Stämpfli \& CIE AG Bern, Bern

Hodson FR (1998) Reflections on Münsingen-Rain with a note on "Münsingen Fibulae". In: Müller F (ed) Münsingen-Rain, ein Markstein der keltischen Archäologie. Funde, Befunde und Methoden im Vergleich. Akten des Internationalen Kolloquiums «Das keltische Gräberfeld von Münsingen-Rain 1906-1996». Verlag Bernisches Historisches Museum, Bern, pp 29-36

Hoefs J (2009) Stable isotope geochemistry, 6th edn. Springer Verlag, Berlin, Heidelberg

Holzhauser H, Magny M, Zumbühl HJ (2005) Glacier and lake-level variations in west-central Europe over the last 3500 years. Holocene 15:789-801. doi:10.1191/0959683605hl853ra

Howcroft R, Eriksson G, Lidén K (2012) Conformity in diversity? Isotopic investigations of infant feeding practices in two Iron Age populations from Southern Oland, Sweden. Am J Phys Anthropol 149:217-230. doi:10.1002/ajpa.22113

$\mathrm{Hu}$ YW et al (2009) Stable isotope dietary analysis of the Tianyuan 1 early modern human. P Natl Acad Sci USA 106:10971-10974

Hug E (1956) Die Anthropologische Sammlung im Naturhistorischen Museum Bern vol 13. Naturhistorisches Museum Bern, Bern

Hunt HV, Vander Linden M, Liu X, Motuzaite-Matuzeviciute G, Colledge S, Jones MK (2008) Millets across Eurasia: chronology and context of early records of the genera Panicum and Setaria from archaeological sites in the Old World. Veg Hist Archaeobot 17:5-18. doi:10.1007/s00334-008-0187-1

Jacomet S, Jacquat C (1999) Ackerbau: Bedeutung der Anbaupflanzen und ihre mögliche Verwendung. In: Kaenel G, Lüscher G (eds) Müller F. Die Schweiz vom Paläolithikum bis zum frühen Mittelalter. SPM IV. Eisenzeit. Verlag Schweizerische Gesellschaft für Ur- und Frühgeschichte, Basel, pp 105-109

Jay M, Richards MP (2006) Diet in the Iron Age cemetery population at Wetwang Slack, East Yorkshire, UK: carbon and nitrogen stable isotope evidence. J Archaeol Sci 33:653-662

Jud P (1998) Untersuchungen zur Struktur des Gräberfeldes von Münsingen-Rain. In: Müller F (ed) Münsingen-Rain, ein Markstein der keltischen Archäologie. Funde, Befunde und Methoden im Vergleich. Akten des Internationalen Kolloquiums «Das keltische Gräberfeld von Münsingen-Rain 1906-1996». Verlag Bernisches Historisches Museum, Bern, 
Jud P, Ulrich-Bochsler S (2014) Bern, Reichenbachstrasse. Die Gräber aus dem Oppidum auf der Engehalbinsel Bern. Archäologischer Dienst des Kantons Bern, Bern

Katzenberg MA (2008) Stable isotope analysis: a tool for studying past diet, demography, and life history. In: Saunders SR, Katzenberg MA (eds) Biological anthropology of the human skeleton. Wiley-Liss, New Jersey, pp 413-441

Katzenberg MA, Herring DA, Saunders SR (1996) Weaning and infant mortality: evaluating the skeletal evidence, vol 39. Anthropology, Yearbook of Physical

Katzenberg MA, McKenzie HG, Losey RJ, Goriunova OI, Weber A (2012) Prehistoric dietary adaptations among hunter-fisher-gatherers from the Little Sea of Lake Baikal, Siberia, Russian Federation. J Archaeol Sci 39:2612-2626. doi:10.1016/j.jas.2011.08.010

Katzenberg MA, Weber A (1999) Stable isotope ecology and palaeodiet in the Lake Baikal region of Siberia. J Archaeol Sci 26:651-659. doi:10.1006/jasc.1998.0382

Kinaston RL, Buckley HR, Gray A (2013) Diet and social status on Taumako, a Polynesian outlier in the Southeastern Solomon Islands. Am J Phys Anthropol 151:589-603

Knipper C et al (2014) Social differentiation and land use at an Early Iron Age "princely seat": bioarchaeological investigations at the Glauberg (Germany). J Archaeol Sci 41:818-835

Kutterer A, Alt KW (2008) Cranial deformations in an Iron Age population from Munsingen-Rain. Switzerland Int J Osteoarchaeol 18: 392-406

Le Bras-Goude G, Herrscher E, Vaquer J (2013) Funeral practices and foodstuff behaviour: what does eat meat mean? Stable isotope analysis of Middle Neolithic populations in the Languedoc region (France). J Anthropol Archaeol 32:280-287

Le Huray JD, Schutkowski H (2005) Diet and social status during the La Tene period in Bohemia: carbon and nitrogen stable isotope analysis of bone collagen from Kutna Hora-Karlov and Radovesice. J Anthropol Archaeol 24:135-147

Lee-Thorp JA, Sealy JC, Van der Merwe NJ (1989) Stable carbon isotope ratio differences between bone collagen and bone apatite, and their relationship to diet. J Archaeol Sci 16:585-599

Lightfoot E, O'Connell TC, Stevens RE, Hamilton J, Hey G, Hedges REM (2009) An investigation into diet at the site of Yarnton, Oxfordshire, using stable carbon and nitrogen isotopes. Oxford J Archaeol 28:301-322

Lightfoot E, Šlaus M, O'Connel TC (2012) Changing cultures, changing cuisines: cultural transitions and dietary changing in Iron Age, Roman and Early Medieval Croatia. Am J Phys Anthropol 148:543-556

Linderholm A, Jonson CH, Svensk O, Liden K (2008) Diet and status in Birka: stable isotopes and grave goods compared. Antiquity 82: 446-461

Longin R (1971) New method of collagen extraction for radiocarbon dating. Nature 230:241-242

Lösch S, Grupe G, Peters J (2006) Stable isotopes and dietary adaptations in humans and animals at Pre-Pottery Neolithic Nevali Cori, southeast Anatolia. Am J Phys Anthropol 131:181-193

Motuzaite-Matuzeviciute G, Staff RA, Hunt HV, Liu XY, Jones MK (2013) The early chronology of broomcorn millet (Panicum miliaceum) in Europe. Antiquity 87:1073-1085

Müller F (1998) Münsingen-Rain, ein Markstein der keltischen Archäologie. Funde, Befunde und Methoden im Vergleich. Akten des Internationalen Kolloquiums «Das keltische Gräberfeld von Münsingen-Rain 1906-1996». Verlag Bernisches Historisches Museum, Bern

Müller F, Jud P, Alt KW (2008) Artefacts, skulls and written sources: the social ranking of a Celtic family buried at Munsingen-Rain. Antiquity 82:462-469

Müller F, Kaenel G, Lüscher G (1999) Die Schweiz vom Paläolithikum bis zum frühen Mittelalter. SPM IV. Eisenzeit. Verlag Schweizerische Gesellschaft für Ur- und Frühgeschichte, Basel
Murphy EM, Schulting R, Beer N, Chistov Y, Kasparov A, Pshenitsyna M (2013) Iron Age pastoral nomadism and agriculture in the eastern Eurasian steppe: implications from dental palaeopathology and stable carbon and nitrogen isotopes. J Archaeol Sci 40:2547-2560

Nehlich O, Fuller BT, Jay M, Mora A, Nicholson RA, Smith CI, Richards MP (2011) Applications of sulphur isotope ratios to examine weaning patterns and freshwater fish consumption in Roman Oxfordshire. UK Geochimica et Cosmochimica Acta 75:4963-4977

Nehlich O, Fuller BT, Márquez-Grant N, Richards MP (2012) Investigation of diachronic dietary patterns on the islands of Ibiza and Formentera, Spain: evidence from sulfur stable isotope ratio analysis. Am J Phys Anthropol 149:115-124

Nielsen NH, Kristiansen SM (2014) Identifying ancient manuring: traditional phosphate vs. multi-element analysis of archaeological soil. J Archaeol Sci 42:390-398. doi:10.1016/j.jas.2013.11.013

Oelze VM et al (2012) Multi-isotopic analysis reveals individual mobility and diet at the early Iron Age monumental tumulus of Magdalenenberg. Germany Am J Phys Anthropol 148:406-421

Papathanasiou A, Panagiotopoulou E, Beltsios K, Papakonstantinou MF, Sipsi M (2013) Inferences from the human skeletal material of the Early Iron Age cemetery at Agios Dimitrios, Fthiotis, Central Greece. J Archaeol Sci 40:2924-2933

Privat KL, O'Connell TC, Hedges REM (2007) The distinction between freshwater- and terrestrial-based diets: methodological concerns and archaeological applications of sulphur stable isotope analysis. J Archaeol Sci 34:1197-1204

Prowse TL, Schwarcz HP, Saunders SR, Macchiarelli R, Bondioli L (2005) Isotopic evidence for age-related variation in diet from Isola Sacra. Italy Am J Phys Anthropol 128:2-13. doi:10.1002/ajpa.20094

Redfern RC, Millard AR, Hamlin C (2012) A regional investigation of subadult dietary patterns and health in late Iron Age and Roman Dorset. England J Archaeol Sci 39:1249-1259

Richards MP, Fuller BT, Hedges REM (2001) Sulphur isotopic variation in ancient bone collagen from Europe: implications for human palaeodiet, residence mobility, and modern pollutant studies. Earth Planet Sc Lett 191:185-190. doi:10.1016/S0012-821x(01)00427-7

Richards MP, Fuller BT, Sponheimer M, Robinson T, Ayliffe L (2003) Sulphur isotopes in palaeodietary studies: a review and results from a controlled feeding experiment. Int J Osteoarchaeol 13:37-45

Rösing FW et al (2007) Recommendations for the forensic diagnosis of sex and age from skeletons. Homo-Journal of Comparative Hum Biol 58:75-89

Rummel S, Hölzl S, Horn P (2007) Isotopensignatur von Bio- und GeoElementen in der Forensik. In: Herrmann B, Saternus KS (eds) Biologische Spurenkunde; Kriminalbiologie. Springer, Berlin, Heidelberg, pp 381-407

Sankot P (1980) Studie zur Sozialstruktur der nordalpinen Flachgräberfelder der La-Tène-Zeit im Gebiet der Schweiz Zeitschrift für Archäologie und Kunstgeschichte 37:19-71

Satrapová J, Hyvönen T, Venclová V, Soukup J (2013) Growth and reproductive characteristics of $\mathrm{C} 4$ weeds under climatic conditions of the Czech Republic. Plant Soil Environ 59:309-315

Scheeres M, Knipper C, Schönfelder M, Hauschild M, Siebel W, Alt KW (in press) Bioarchaeometric investigations $(87 \mathrm{Sr} / 86 \mathrm{Sr}$ and $818 \mathrm{O})$ of the La Tène burial community of Münsingen-Rain; Switzerland. In: Arnold B (ed) The Oxford handbook of the archaeology of the continental Celts. Oxford University Press, Oxford,

Scheuer L, Black S (2000) Development juvenile osteology. Academic, London

Schibler J, Stopp B, Studer J (1999) Haustierhaltung und Jagd. In: Kaenel G, Lüscher G (eds) Müller F. Die Schweiz vom Paläolithikum bis zum frühen Mittelalter. SPM IV. Eisenzeit. Verlag Schweizerische Gesellschaft für Ur- und Frühgeschichte, Basel, pp 116-136

Schmidl A, Jacomet S, Oeggl K (2007) Distribution patterns of cultivated plants in the Eastern Alps (Central Europe) during Iron Age. J Archaeol Sci 34:243-254 
Schoeninger MJ, DeNiro MJ (1984) Nitrogen and carbon isotopic composition of bone-collagen from marine and terrestrial animals. Geochimica Et Cosmochimica Acta 48:625-639. doi:10.1016/ 0016-7037(84)90091-7

Sjøvold T (1988) Geschlechtsdiagnose am Skelett. In: Knussmann R (ed) Anthropologie. Handbuch der vergleichenden Biologie des Menschen. Gustav Fischer Verlag, Stuttgart, New York, pp 444-480

Stevens RE, Hedges REM (2004) Carbon and nitrogen stable isotope analysis of northwest European horse bone and tooth collagen, 40, 000 BP-present: palaeoclimatic interpretations Quaternary. Sci Rev 23:977-991. doi:10.1016/j.quascirev.2003.06.024

Stevens RE, Jacobi RM, Higham TFG (2010) Reassessing the diet of Upper Palaeolithic humans from Gough's Cave and Sun Hole, Cheddar Gorge, Somerset, UK. J Archaeol Sci 37:52-61

Stevens RE, Lightfoot E, Hamilton J, Cunliffe BW, Hedges REM (2013) One for the master and one for the dame: stable isotope investigations of Iron Age animal husbandry in the Danebury. Environs Archaeol Anthropol Sci 5:95-109

Stevens RE, Lister AM, Hedges RE (2006) Predicting diet, trophic level and palaeoecology from bone stable isotope analysis: a comparative study of five red deer populations. Oecologia 149:12-21. doi:10. 1007/s00442-006-0416-1

Stewart MM, Larocque-Tobler I, Grosjean M (2011) Quantitative interannual and decadal June-July-August temperature variability ca. $570 \mathrm{BC}$ to AD 120 (Iron Age-Roman Period) reconstructed from the varved sediments of Lake Silvaplana. Switzerland J Quaternary Sci 26:491-501. doi:10.1002/Jqs. 1480

Stika HP (1996) Traces of a possible Celtic brewery in EberdingenHochdorf, Kreis Ludwigsburg, southwest Germany. Veg Hist Archaeobot 5:81-88. doi:10.1007/Bf00189437

Stika HP (2011) Early Iron Age and Late Mediaeval malt finds from Germany - attempts at reconstruction of early Celtic brewing and the taste of Celtic beer. Archaeol Anthropol Sci 3:41-48
Stöckli WE (1975) Chronologie der jüngeren Eisenzeit im Tessin. Verlag Schweizerische Gesellschaft für Ur- und Frühgeschichte Basel, Basel

Szilvássy J (1988) Altersdiagnose am Skelett. In: Knussmann R (ed) Anthropologie. Handbuch der vergleichenden Biologie des Menschen. Gustav Fischer Verlag, Stuttgart, New York, pp 421-435

Tütken T, Langenegger E, Wild W (2008) Native or not? Isotope analysis of a female skeleton on the 9th century AD from Elsau, Canton Zurich, Switzerland. Anthropol Anz 66:19-50

Uerpmann A (2005) Schädeldeformationen im eisenzeitlichen Gräberfeld Münsingen-Rain (Schweiz). Johannes Gutenberg University, Master's thesis

Ugan A, Coltrain J (2011) Variation in collagen stable nitrogen values in black-tailed jackrabbits (Lepus californicus) in relation to smallscale differences in climate, soil, and topography. J Archaeol Sci 38:1417-1429. doi:10.1016/j.jas.2011.01.015

Van Klinken GJ, Hedges REM (2000) An overview of causes for stable isotopic variations in past European human populations: environmental, ecophysiological, and cultural effects. In: Ambrose SH, Katzenberg MA (eds) Biogeochemical approaches to paleodietary analysis. Kluwer Academic/Plenum Publishers, New York, pp 39 63

Vika E (2009) Strangers in the grave? Investigating local provenance in a Greek Bronze Age mass burial using delta S-34 analysis. J Archaeol Sci 36:2024-2028

Wiedmer-Stern J (1908) Das Latène-Gräberfeld bei Münsingen (Kt. Bern) Archiv des Historischen Vereins des Kantons Bern 18:269361

Wyss R, Rey T, Müller F (2002) Gewässerfunde aus Port und Umgebung. Katalog der latène- und römerzeitlichen Funde aus der Zihl. Schriften des Bernischen Historischen Museums 4. Verlag Bernisches Historisches Museum, Bern 